This item was submitted to Loughborough's Research Repository by the author.

Items in Figshare are protected by copyright, with all rights reserved, unless otherwise indicated.

\title{
Revisiting diaspora as process: timespace, performative diasporas?
}

PLEASE CITE THE PUBLISHED VERSION

https://doi.org/10.4337/9781786436030

PUBLISHER

Edward Elgar Publishing

VERSION

AM (Accepted Manuscript)

PUBLISHER STATEMENT

This is a draft chapter. The final version is available in Handbook on Critical Geographies of Migration edited by Katharyne Mitchell, Reece Jones and Jennifer L. Fluri, published in 2019, Edward Elgar Publishing Ltd https://doi.org/10.4337/9781786436030. The material cannot be used for any other purpose without further permission of the publisher, and is for private use only.

\section{LICENCE}

All Rights Reserved

\section{REPOSITORY RECORD}

Mavroudi, Elizabeth. 2019. "Revisiting Diaspora as Process: Timespace, Performative Diasporas?". Loughborough University. https://hdl.handle.net/2134/12932870.v1. 
Please cite as Mavroudi, E. (2019) Revisiting diaspora as process:

timespace, performative diasporas? in K. Mitchell, R. Jones and J. Fluri (eds)

Handbook on Critical Geographies of Migration, Edward Elgar, 279-290

\title{
Revisiting diaspora as process: timespace, performative diasporas?
}

\author{
Elizabeth Mavroudi \\ Loughborough University
}

Abstract

There are tensions between the roots and routes of diaspora, on the one hand stressing fluid, hybrid lives and identities 'on the move' whilst on the other, the constant striving for connectedness with, and belonging to, the homeland (Clifford 1997; Mavroudi 2007a). These dynamic boundary (de)constructions (Brubaker 2005) can be empowering, but also problematic for those in diaspora and serve as a reminder that we need to pay attention to the complex power relations, materiality, ambivalence and potential challenges of living, feeling and belonging in diaspora. For geographers, one of the main concerns has been to flesh out the materialities and emotionalities of diaspora through a grounding of place, and the explorations of spaces and times which affect the diasporic experience. This chapter builds upon these themes by focusing on two cross-cutting and inter-linking themes as a means of further engaging with the notion of diaspora as process: diasporas and timespace and linkages between diasporas, mobilities and non-representational theory or diasporas as performed and negotiated. In doing so, the chapter will also seek to highlight the important role that geographers can play in debating such issues, and in doing so, making theoretical contributions to conceptualising diaspora.

Keywords: diaspora, process, timespace, non-representational theory, mobilities

\section{Introduction}


There are tensions between the roots and routes of diaspora, on the one hand, stressing fluid, hybrid lives and identities 'on the move' whilst on the other, the constant striving for connectedness with, and belonging to, the homeland (Clifford 1997; Mavroudi 2007a). These dynamic boundary (de)constructions (Brubaker 2005) can be empowering, but also problematic for those in diaspora and serve as a reminder that we need to pay attention to the potential challenges of living, feeling and belonging in diaspora through time and space.

Conceptualising diasporas as process rather than a static group or community tries to address such tensions, and accounts for these evolving, myriad and often difficult relationships across and within boundaries (Mavroudi 2007a and b; 2008; 2010). Being in diaspora often requires flexibility, creativity, adaptivity as notions of home and belonging can be more complex to articulate. Diasporic identities may be constructed in more essentialised, ethno-national, fixed ways for strategic, emotional reasons (Mavroudi 2007b). However, the reality of diasporic lives and identities is often in-between, hybrid, and ambivalent. Diasporic identities, lives, spaces, times and connections with host country/homeland are complex, dynamic, grounded, gendered, historicised and contextualised. By viewing diaspora as an ongoing, active process, those in diaspora are imbued with agency; they are neither static beings blindly following primordial attachments and territorialisation or untethered postmodern nomads, freely swaying in the winds of uncontrolled globalisation and cross-border connections. It is a way of unravelling, dissecting and following such complex cross-border connections, stressing the need to ask critical questions about the nature, intensity, reality and repercussions of such linkages without resorting to easy or simplistic assumptions. It also potentially allows for the recognition of the messiness and arbitrary, confusing, hard-to-explain or rationalise actions, feelings and experiences of those in diaspora.

This chapter builds upon these themes by focusing on two cross-cutting and inter-linking themes as a means of further fleshing out and engaging with the notion of diaspora as process: diasporas and timespace and linkages 
between diasporas, mobilities and non-representational theory or diasporas as performed and negotiated. In doing so, the chapter will also seek to highlight the important role that geographers can play in debating such issues, and in doing so, making theoretical contributions to conceptualising diaspora.

\section{Debating the meanings of diaspora}

Despite the many uses of the word diaspora, there are arguably three main ways in which diasporas can be conceptualized (Brubaker 2005; Mavroudi 2007a). Firstly, diasporas can be seen in more 'static' ways, as defined, dispersed, and displaced communities or entities held together by common traditions, histories, ethnicities, nations and religions that centre around a homeland (Cohen 1997; Sheffer 1999); the Jewish diaspora is often perceived to be such an archetypal diaspora. Secondly, diasporas can be understood as imagined, constructed and fluid in the sense that diasporic lives and identities are perceived to be 'on the move', transgressing and moving beyond boundaries, borders and the nation-state, exemplified by ideas such as Yeoh and Huang's $(2000,415)$ 'diaspora as a journey idea': "not unidirectional, or even circular, but often ridden with disruptions, detours, and multidestinations". Therefore, on the one hand, traditional definitions of diaspora centre on the creation of boundaries (of identity, community and the nationstate): a focus on roots and the homeland. On the other hand, postmodern conceptualisations of diaspora are based on ideas of fluidity, movement, routes and the destabilisation of (potentially) homogenising boundaries (of for example, identity, community and the nation-state). Here, identities are seen as fluid, flexible, malleable, and as constantly 'in-the-making' (Hall 1999; Papastergiadis 2004). Those in diaspora may be involved in connections, flows, and networks, creating hybrid, 'diasporic spaces' (Brah 1996) of potentially flexible citizens across national borders (Ong 1998), who hold plural identities negotiated differently through time and space (Burdsey 2006, Dwyer 1999, Blunt 2007; Kalra et al 2006). This suggests that diasporas operate beyond nation-state borders, challenging the nation-state with postnational attachments and belonging (Soysal 1998). However, at the same time, diasporas are grounded in places, and nations and nation-states 
continue to influence those in diaspora (Wimmer and Glick Schiller 2002; Kalra et al 2006).

Therefore, as Werbner $(2002,120)$ has noted: "diasporas, it seems, are both ethnic-parochial and cosmopolitan". This leads to the third way of conceptualising diasporas, which tries to incorporate the approaches above; it stresses the need to account for plural, dynamic, malleable diasporic identities and belonging. However, at the same time, it aims to ground such identities and lives and bring to the fore the potential realities of power struggles, strategic essentialisms, tensions and ambivalences of those in diaspora as they negotiate identity, politics and cross-border connections. It is this which diaspora as process attempts to do.

Scholars have addressed the tensions between these different approaches as a roots and routes debate (Gilroy 1993), and as the need to engage with boundedness and unboundedness or boundary erosion and creation (Brubaker 2005). Gilroy (1993), in his work on black populations on both sides of the Atlantic used the 'Black Atlantic' as a single, complex unit of analysis and in doing so, rallied against ethnic absolutism and purity of cultures. He viewed cultural identities as based around continuity and rupture, sameness and difference; their 'double consciousness' meant that Black African slaves were seen as agents, as racialised, victimised, oppressed but also with elements of control and creativity. However, he also distanced himself from hybridity and purely celebratory accounts of diaspora routes and critiqued them for being potentially elitist. He therefore stressed the need to account for both the roots and routes of the Black Atlantic diaspora (Gilroy 1993). Similarly, Clifford's work $(1997,269)$ pays attention to the 'here' and 'there' of diaspora, highlighting that 'there is not necessarily a single place or an exclusivist nation.' Cultures and identities are therefore seen as mixed and plural and 'on the move', yet his approach is also based very much in grounded everyday lives and practices. The idea of roots and routes being important therefore helps to account for the ambivalence and potential tensions those in diaspora feel in relation to both. 
More recently, but very much based on such ideas, diasporas have been conceptualised as incomplete and 'becoming' (Morawska 2011) and as a process (Houston and Wright 2000), potentially struggling to belong (Mavroudi 2010; Christou 2011, Hopkins et al 2012) and be political (Yeh, 2007; Mavroudi, 2008a; 2008b; McConnell 2015; Demir 2015). Houston and Wright (2000, 219) for example, have written about the Tibetan diasporas, referring to the ways in which the diaspora is constantly in the making: "[this] elucidates the continual creation of composite Tibetan refugee identities and spaces". Those in diaspora can feel torn between: spaces and networks centered on the homeland, loyalties to ethnic, national, or religious group-based identities in the host country or homeland on the one hand, and on the other, personal negotiations of their own complex, individual identities and the messiness, difficulties and ambivalences of living and feeling between here and there.

Defining who does and does not belong to a diaspora has become a customary exercise, particularly in more traditional understandings which privilege ethno-national, religious and territorial connections amongst those in the diaspora and with the homeland. Yet, defining who belongs to a diaspora needs to take emotion into account (Mavroudi and Christou 2015) and to acknowledge that "not all biographically-connected individuals wish to be part of a country's diaspora, whilst others may feel connected to more than one diasporic community" (Jöns et al 2015, 32). We need to pay attention to such issues and the fact that flexible, inclusive, open-ended notions of diaspora are needed as those in diaspora grapple with issues such as identity, belonging, mobility, development and politics whilst being positioned and juxtaposed between here and there.

Diaspora as process is a notion which attempts to capture such ideas and issues. Rather than seek to close or box in, categorise, attribute characteristics to those in diaspora, the notion of process is more open and inclusive. It allows for those who may wish to stress certain group similarities and make comparisons and generalisations but it also always highlights the difficulties in doing so, and the importance of the idea that there is no one way to feel and be in diaspora. In other words, we need to pay attention to the 
emotional and embodied individuals which make up diasporas, as well as the ways in which they negotiate, work (or struggle) together, the ways they connect, and disconnect with eachother and across borders, and the intricate, myriad, plural ways to be and belong.

Geographers stress the importance of recognising differences over time and space and the impacts that diaspora can have on the state and issues such as gender, class and power relations. Geographical analyses of diaspora also enable the exploration of the process of constructing 'sameness' or collective 'diasporic consciousness', as well as difference. As Werbner $(2004,896)$ succinctly notes:

Diasporic communities create arenas for debate and celebration. As mobilised groups, they are cultural, economic, political and social formations in process... This means that diasporas are culturally and politically reflexive and experimental; they encompass internal arguments of identity about who 'we' are and where we are going. Diasporas are full of division and dissent. At the same time they recognise collective responsibilities, not only to the home country but to co-ethnics in far-flung places.

Diaspora needs to be a broad, open-ended notion that is able to take into account, as Werbner notes, of the cultural, economic, political and social 'formations in process'; such an approach which recognises the complexities and the disjointed potential merging of such factors is useful.

What arguably makes such negotiations more complex is time and space and the ways in which such identities, lives, feelings, perceptions and actions are constantly and actively performed and re-constituted in specific, but connected places. Although space, place and time often form part of discussions on diaspora, there is arguably a need for further conceptualisation and research which brings them to the fore even more, and in more innovative ways. Blunt $(2005,10)$ has argued: "while geography is clearly central to 
understanding diaspora both in theory and practice, ideas about diaspora also raise questions about space and place". This stresses the need to further explore the contribution that geographers have, and can, make, particularly in relation to notions of space, time and place. Carter $(2005,55,56)$ also points out that "the diaspora literature has failed...to fully explore this transformation of space, beyond re-stating that diaspora consciousness opens up a rift between location and identity" and that as a result, there has been an "inadequate treatment" of territory and of politics. There is, therefore, ample work for geographers to do in this respect. However, they also have a role to play in examining the complex dynamics and tensions that arise as those in diaspora negotiate a juxtaposition of the here and there, past and present, colonial and postcolonial which constitute messy times and spaces that would appear to defy simplistic categorization and representation. It is for such reasons that it is arguably useful for geographers working on diaspora to engage with non-representational theory, and more specifically, the idea of performative timespace.

\section{Diaspora as process in performative timespace}

Early work on timespace in geography can be traced to Hägerstrand's (1970) time-geography diagrams which viewed the world, and of how individuals moved in places in visual, embodied, connected but also ordered and constrained ways. As a philosophical approach it challenged geographers to think more critically about the relationships between space and time so that the two were inter-related but not completely collapsed. His 'space-time path' stressed that time continuously affects spatial movements and that people, and their desired 'projects' and activities are important processes within this even as they may be constrained (Hägerstrand 1982). Despite criticisms (see Lenntorp 1999), his work continues to have significance, primarily because of the way he deals with time and space as non-dualistic and connected (Thrift and Pred 1981; May and Thrift 2001). His work has been important in the writing of Alan Pred (1984), Nigel Thrift (1996), and Doreen Massey (2005) amongst others and it has been used in feminist research (Kwan 1999) 
although Kwan also stressed the importance of using rich ethnographic data as well as the GIS based approach used in the paper. More recently, Carling (2017) has used migration history charts to visually present the trajectories of interviewees and their family members and are based on detailed qualitative data. Like Carling whose work focuses on transnational migration, many contemporary uses of timespace in geography have moved beyond Hägerstrand's understanding of space as finite, and absolute.

Lenntorp (1999) stressed how time-geography continues to have salience in, and can strengthen geographical analyses and beyond, and in relation to different themes and issues but primarily in theory-building, which is what this chapter attempts to do. Schwanen and Kwan (2012) have also argued that the ways in which the geographies of difference and inequality are played out have not been adequately theorised from a spatiotemporal perspective. This means that the geographies of marginalisation and exclusion still require more research and analysis in relation to time and space. It also serves as a reminder that the critical geographies of migration and diaspora need to explore and unravel the complex ways migrants and those in diaspora might be marginalised, excluded and disempowered through conjunctions and juxtapositions of time and space and as a result of intersections of race, class, gender and so forth. Viewing migration and diaspora through the lens of timespace can help in this respect. However, Merriman (2012) sounds a word of caution in how timespace has been used in foundational and a priori ways in geography, particularly by scholars such as Thrift and Massey. In other words, he suggests that time and space have themselves become used in primordial, normative ways and this closes off the possibility of examining space and time separately as well as together.

As a potential way forward, Page et al (2017) ask how the exploration and recognition of the differences between space and time can become a practical project, whilst at the same time acknowledging that time and space cannot be treated separately. They argue that language could be used as a helpful metaphor whereby time and space are seen as different languages, which exist and make sense separately, but can also be viewed together, 
relationally, through a process of partial translation where there are similarities and differences. Such an approach echoes other work in transnational migration and diaspora studies which stresses the provisional nature of diaspora as process, and the ways in which time, space and place are used and negotiated by those in diaspora (Mavroudi 2007b) in what Nagel (2002) called the politics of 'sameness' and 'difference'. By explicitly utilising a timespace approach, migration and diaspora scholars may usefully pay attention to space and time in more critical, innovative, untethered ways but without throwing away time and space as separate concepts and realities. In doing so, there is a committment to seeing diaspora as 'becoming', on the move, enabled but also as potentially constrained through timespace. If, in turn, we see diaspora as an active process, in which doing, feeling, experiencing, and performing occurs in particular places, times and spaces but in open-ended, flexible, non-static ways, we can then start to discuss the potential relevance of non-representational theories (Mavroudi, 2017).

The notion of timespace stresses that what we see and perceive is not isolated or separate but takes place in motion, in everyday time, and as a result, connectedness is paramount (Mavroudi 2017). As a result, we are constantly sensing and experiencing in and through timespace, not separately from it: it forms part of our everyday lives in tangible and intangible ways (Crang 2001,196). However, in timespace, space and time can become potentially disrupted and juxtaposed, rendering experience a sensory, embodied one which is both in tune but also out of sync with one's daily life, rhythms, memories, emotions and past experiences and knowledges and so forth. For scholars exploring the lives and identities of those in diaspora, such an approach may offer useful insights into the complex ways feelings of displacement, exile, rupture, disconnectedness and difference jar and jostle with belonging, connectedness and shared consciousness. In addition, it provides a way to help make sense of such experiences and feelings in a more holistic manner, linking material and immaterial worlds, in order to examine them in and through timespace. This might then enable the opening up and partial revealing of different, unseen, unknown and hidden aspects of such lives and identities 'on the move'. In a timespace approach, times and 
spaces are slippery, both merging and separate, connected and disconnected as those in diaspora are constrained and enabled by their grounded, embodied, historicised, gendered materialities and emotionalities. This is a performative way of viewing the world, one which refuses to be pigeon-holed by concrete representations: it is non-representational in that the active 'doing' and experiencing is constant, elusive and uncontainable by conventional representations. The concern is very much with the 'doing' in everyday life, the actual practices that constitute continuous moments of performance (Lorimer 2007, 96).

Geographers engaging with the notion of performance stress the need to see everyday life as a series of continuous actions and practices that are materialised, unique, connected and unquantifiable in the sense that they are moments in timespace that are elusive yet practiced and experienced in particular ways. Representations are seen as limiting because they attempt to state and describe and as a result, close off alternative and creative understandings and experiences of space, place and time (Thrift and Dewsbury 2000). Therefore, performance and non-representation are seen as ongoing processes which are difficult to pin down, but which form part of daily life (Thrift 2008). As Nash (2000, 657) points out: "the value of ideas of performance and practice is their challenge to forms of interpretation which focus on the representation of meaning in visual or literary texts or use textual analysis to understand the world".

However, as Tolia-Kelly $(2006,213)$ stresses, we need to be aware of what is "occluded in the writing on affect" and that bodies are subject to power relations and geometrics that make it difficult for people to act. She, like Nash (2000) has warned against nonrepresentational writing that is ahistorical, universalistic and ethnocentric. Jones (2011) has also pointed out that it ignores the past, and memories, focusing too much on the present and the 'doing'. Such critiques rightly highlight the need to consider that the processes of power and control within different spaces, times and scales are important as struggles occur over representation, negotiation and performance of difference. Such power relations and historical, gendered, classed, racialised 
contexts and positionalities need to be addressed in the geographies of diaspora. Therefore, non-representational theory has been found apolitical and lacking, with its focus on practice and the near obsession of methods which celebrate the mobile, the rhythmic and the performative as opposed to a grounded politics of place:

We acknowledge the validity of NRT [non-representational theory] as a philosophical intervention but deplore its increasing use as method in empirical research. In the work of many (but not all) proponents of NRT we see not an opening of the entrenched battle lines of what constitutes the political but rather, through the elision of geographical methods which elicit social interrelations and historical patterns, an inversion of politics - the extension of a mode of thought that we believe to be profoundly depoliticizing (Mitchell and Elwood 2012, 789)

Such critique reminds us of the importance of both research methods and analysis which pay attention to the ways in which people might be, and are, political, and the limitations to potential empowerment and political action. For diaspora studies, which itself has been critiqued for not focusing enough on the political (Carter 2005) and linked to this, the national (Dirlik 2006) as well as the historical (Dirlik 2002), there is a need for conceptualisations which are inclusive enough to both gather a wide range of experiences, identities and practices. However, they also need to powerful and robust enough to stand up to theoretical scrutiny rather than become fixated on matters such as definitions of diaspora, the description and analysis of diasporic identities, lives, politics, cultures and practices as either ethno-national or hybrid-plural, or as performative or representational.

Borrowing ideas from performative, non-representational theory, and using the notion of timespace allows research on the geographies of diaspora to go further, and to push the limits of our analysis and conceptualisation. To do this, there is scope for exploring how and why people represent and perform and how they may be limited and empowered by both. As Laurier and Philo 
(2006) point out, we can engage with representation as well as performance; in other words despite the criticism representation has received, it is still possible to "accept representation as one of many possible expressive practices, one correlate of which is greatly to expand our understanding of the terrain of representation beyond the word, spoken, or written". Researching representations still remains important, in order to come to terms with how constructions of identity, for example, are created and maintained in potentially static and singular ways. One could further argue that the politics of representation has the potential to liberate peoples who choose to represent themselves in certain (potentially essentialised) and unified ways to get messages across.

By viewing diasporic lives, bodies, feelings and experiences as performative, one can arguably deconstruct representations more readily, as embodiments, emotions and acts that are fluid, yet also contextualized within a changing environment. Diaspora as process can therefore be conceptualised as a notion which allows for the analysis of active, performative, mobile timespace materialities and dynamic practices and the ways in which migrants and those in diaspora might use representations in more static or strategic ways for specific reasons. According to non-representational theory, authenticity itself is problematic, but also redundant. There may continue to be claims to authenticity and truth but one could argue that these form part of the endless performances of everyday life, in which politicisation and the state dictates a need for 'authentic' practices, places and representations. Place, although continuously claimed, sought for, memorialised and so forth, needs to be seen as one part of performance and is incorporated into timespace. If identities are to be seen as in-the-making, we need to critique attempts to define them and be open to attempts that allow flexible and open-ended identities that are positioned and grounded. In this way, place continues to be important, but it is not static anymore because it is dependent on, and forms part of, connections and mobilities. It is not inert and passive, but is part of life-worlds, timespace and performances. 
Mobility, and being 'on the move' conjures up dynamic temporality, and the focus in performative research and non-representational theory is often on movement: "However, a research agenda addressing such mobilities need not embrace them as a supposed form of freedom or liberation from space and place" (Sheller and Urry 2010, 210). Indeed, the notion of timespace incorporates and necessitates mobility. The world is one which is seemingly in motion and our perceptions, bodies and consciousness are too, even as they are constantly connected to but also jolting against and juxtaposed with other times and spaces in messy ways. In doing so, at particular moments, time and space are fractured or disrupted as a result of what we see, perceive and experience. Through such performance, which is linked to the everyday, what those in diaspora experience becomes part of their everyday lives, bodies, emotions, pasts and presents, reminiscent of "the serenity of the Greek kairos: what we might call the temporal opportunities of everyday life" (Maffesoli 1998, 268). Here, the notion of 'kairos' conjures up ever-changing weather, the constant process of weathering in the landscape, as well as being in and part of time and space, and located in place, with particular, but also dynamic, patterns and rhythms.

Non-representational theory and a focus on mobilities may, methodologically, have profound limitations because of the focus on temporality and the moment, rather than on representation and the outcomes of such representational processes. However, as Cresswell (2010) outlines, in relation to mobilities, examining movement does not have to come at the expense of history, immobility, politics or representation. In addition, the use of nonrepresentational theory as a way to think more critically about timespace for those in diaspora might arguably be welcome, not as means to ignore context, or the materialities of factors such as race, gender, history, place or politics, or to ignore the communal at the expense of the individual. Rather, in its treatment and elevation of timespace, it allows us the potential to think more creatively and expansively about the ways in which those in diaspora engage with their identities and lives in and through timespace in more complex ways. By honing in on being and becoming, on the now, on the present, it allows us 
to think through the intimate connections between time, space and place and stresses the realities of how people actually live and feel in mobile, dynamic ways. People's lives and identities are not suspended in time and space vacuums, with each neatly separated out for us to examine as scholars. We need ways of researching lives, identities, feelings and embodied practices which are more in tune with the complexities of lives on the move, in multiple places, across borders, times and spaces. It is perhaps, an extension of Massey's relational and political sense of place: "it is in the terms of engagement among these intersecting trajectories that lie the politics, the productivity, the questions, the expectations, the potential for surprise" (Massey 2003, 118).

\section{Concluding thoughts: diasporas as process in-between representation and performance?}

Rather than unbridled adherence to non-representational theory, the linking of diaspora with timespace allows us to potentially take some of the more positive aspects of non-representational theory - the focus on the temporal, embodied and the performative - with the groundedness and connectedness of timespace imagined in more holistic ways: that timespace is not just a celebration of the here and now and all that encompasses, but also stretches to include past and present, here and there timespace. It is an inclusive notion, one which incorporates what is present, but can also account for what is missing, what is occluded, power relations which cross-cut and may be hidden because it pays attention to both time and space simultaneously, it also opens up deeper articulations of place and what it means to be and feel and inhabit that place as a specific, gendered, racialised, embodied individual, who experiences timespace on their own but also in relation to others. In doing so, different, creative ways to be political and to make connections through timespace such as through social media, in and across generations may be found.

For diaspora, it potentially enables a more critical and nuanced exploration of the (dis)connections between people and place, locating their grounded lives, identities, feelings and practices in and through timespace, in active, dynamic 
ways. Through such diaspora as process, it may then be possible to examine both the politics of representation, of struggle, of identity, as well as the fluid ways those in diaspora might be political as they perform and negotiate and practice their lives and identities in embodied and emotional ways. As such, viewing their lives through a timespace non-representational lens does not mean their politics, or ways to be political within and across borders are ignored or negated. It is precisely as a result of the focus on active, dynamic, intimate, intricate timespace juxtapositions of here, there, past, future, them, us within individual, but also shared diasporic lives that may allow us to discover surprising new ways to be and feel in diaspora. This, in turn, also means that we might need to borrow some of the research methods used by non-representational theorists and by those focusing on mobilities, in order to try and further make sense of the complex, and border and boundary crossing mobilities (and stasis) in diasporic lives and identities. This is not a substitute for the already excellent research on diasporas which use more traditional research methods. Rather, it is a call for geographers (and non-geographers) to be open to innovative or different methods (using and analysing, for example, social media, new forms of mapping and GIS, visual and virtual analysis, participatory action research, mobile ethnographies, timespace diaries and so forth) when it comes to analysing diaspora (im)mobilities in this age of globalisation and technological connection. As Sheller and Urry (2010, 222) aptly note in relation to what they call the new mobilities paradigm but which is also relevant for diaspora studies:

New mobilities are bringing into being new surprising combinations of presence and absence as the new century chaotically unfolds.

Methods and theories will need to be ever on the move to keep up with these new forms of mobilities, new systems of scheduling and monitoring, and new pervasive modes of mobilised social inclusion/exclusion.

In addition, it is also a plea for geographers to engage more deeply with the complex ways in which those in diaspora live, feel and operate in mobile timespace, by focusing on the everyday, on how the here and the now 
connects with there, and the past in simultaneous, potentially political ways. In doing so, it recognises the constraining structures and enabling opportunities faced by those in diaspora by situating, placing and tracing individuals, with their own power assemblages, within multiple contexts, networks and timespaces.

\section{Reference List}

Blunt, A. 2007. Cultural geographies of migration: Mobility, transnationality and diaspora. Progress in Human Geography 31, 684-94.

Blunt, A. (2005), Domicile and diaspora: Anglo-Indian women and the spatial politics of home Blackwell, London

Brah A. (1996), Cartographies of diaspora. London: Routledge.

Brubaker, R. (2005), 'The 'diaspora' diaspora', Ethnic and Racial Studies 28 (1), 1-19.

Carling, J. (2017) On conjunctures in transnational lives: linear time, relative mobility and individual experience in Mavroudi, E, Page, B and Christou, A. (eds forthcoming) Timespace and international migration, Edward Elgar

Carter, S. (2005), 'The geopolitics of diaspora', Area 37 (1), 54-63.

Christou, A. and Mavroudi, E. (eds 2015), Dismantling Diasporas: Rethinking the Geographies of Diasporic Identity, Connection and Development, London: Ashgate .

Christou, A. (2011), 'Narrating lives in (e)motion: Embodiment, belongingness and displacement in diasporic spaces of home and return'. Emotion, Space and Society 4, 249-257. 
Clifford, J. (1997), Routes: travel and translation in the late twentieth century Harvard University Press, Cambridge.

Cohen, R. (1997), Global Diasporas UCL Press, London

Crang, M. (2001), 'Rhythms of the City: Temporalised Space and Motion', in Jon May and Nigel Thrift (eds) Timespace: Geographies of Temporality, London: Routledge, 187-207.

Cresswell, T. (2010), 'Towards a politics of mobility', Environment and Planning D: Society and Space, 28, 17 - 31.

Dirlik, A. (2006), 'Intimate others: [private] nations and diaspora in an age of globalisation', Inter-Asia Cultural Studies, 5, 491-502

Dirlik, A. (2002), 'Literature/identity: Transnationalism, narrative and representation', Review of Education, Pedagogy, and Cultural Studies, 24 (3), 209-234.

Dwyer, C. (1999), 'Contradictions of community: questions of identity for young British Muslim women' Environment and Planning A, 31 53-68.

Gilroy, P. (1993), The Black Atlantic: modernity and double consciousness, Routledge, London.

Hägerstrand, T. (1970), 'What about people in regional science?', Papers in regional science, 24(1),7-24.

Hägerstrand, T. (1982), 'Diorama, Path and Project,' Tijdschrift Voor Economische En Sociale Geografie, 73(6),323-339.

Hall, S. (1999), 'Cultural identity and diaspora', In Steven Vertovec and Robin Cohen (eds), Migration, diasporas and transnationalism, Cheltenham: Elgar, 299-314. 
Houston, S and Wright, R. (2003), 'Making and remaking Tibetan diasporic identities', Social and Cultural Geography 4 (2), 217-232.

Jones, O. (2011), 'Geography, memory and non-representational geographies', Geography Compass 5, 875-885.

Jöns, H., Mavroudi, E. and M. Heffernan (2015), 'Mobilising the elective diaspora: German-American academic exchanges in the postwar period' Transactions of the Institute of British Geographers, 40, 113-127.

Kalra, V S, Kaur, R and Hutnyk, J. (2006), Diaspora and hybridity Sage, London.

Kahani-Hopkins, V and Hopkins, N. (2002), 'Representing' British Muslims: the strategic dimension to identity construction, Ethnic and Racial Studies 25 (2), 288-309

Kwan, M. (1999), Gender and individual access to urban opportunities: a study using space-time measures, Professional Geographer (51) 2, 210-227

Lenntorp, B. (1999), Time-geography: at the end of its beginning, GeoJournal, $48,155-158$

Lorimer, H. (2007), 'Cultural geography: worldly shapes, differently arranged', Progress in Human Geography 31(1), 89-100.

Maffesoli, M. (1998), Presentism - or the value of the cycle, Cultural Values 2 (2-3), 261-269.

Massey, D. (2005), For space Sage, London. 
Massey, D. (2003), 'Some Times of Space', in Susan May (ed), Olafur Eliasson - The Weather project, exhibition catalogue, London: Tate Publishing, 107-118.

Mavroudi, E, Page, B and Christou, A. (eds 2017), Timespace and international migration, Edward Elgar

Mavroudi, E. (2017), The timespace of identity and belonging: female migrants in Greece, in Mavroudi, E, Page, B and Christou, A. (eds forthcoming) Timespace and international migration, Edward Elgar

Mavroudi, E. (2010), 'Contesting identities, differences and a unified Palestinian community', Environment and Planning D: Society and Space 28, 239-253.

Mavroudi, E. (2008), 'Palestinians and pragmatic citizenship: negotiating relationships between citizenship and national identity in diaspora', Geoforum 39, 307-318.

Mavroudi, E. (2008), 'Palestinians in diaspora, empowerment and informal political space', Political Geography 27, 57-73.

Mavroudi, E. (2007a), 'Diaspora as process: (De)constructing boundaries', Geography Compass 1, 467-79.

Mavroudi, E. (2007b), 'Learning to be Palestinian in Athens: constructing diasporic national identities'. Global Networks 7: 392-412.

May, J and Thift, N. (eds) (2001), TimeSpace: Geographies of temporality, London and New York: Routledge.

Merriman, P. (2012), Human geography without time-space, Transactions of the Institute of British Geographers 37 13-27 
Mitchell, K and Elwood, S. (2012), 'Mapping children's politics: the promise of articulation and the limits of nonrepresentational theory', Environment and Planning D: Society and Space 30, 788 - 804.

Morawska, E. (2011), 'Diaspora' diasporas' representations of their homelands: exploring the polymorphs, Ethnic and Racial Studies 34 (6), 10291048.

Nagel, C. (2002), 'Constructing difference and sameness: the politics of assimilation in London's Arab communities', Ethnic and Racial Studies 26 (2), 258-287.

Nash, C. (2000), 'Performativity in practice: some recent work in cultural geography', Progress in Human Geography 24 (4), 653-664.

Ong, A. (1999), Flexible citizenship: the cultural logics of transnationality Duke University Press, London and Durham.

Papastergiadis, N. (2004), The Turbulence of Migration. London: Polity Press

Pred, A. (1984), Place as historically contingent process: structuration and the time-geography of becoming places, Annals of the Association of American Geographers 74 (2) 279-297.

Samers, M. (2003), 'Diaspora unbound: Muslim identity and the erratic regulation of Islam in France', International Journal of Population Geography 9, 351-364.

Sheffer, G. (1999), 'The emergence of new ethno-national diasporas', in Steven Vertovec and Robin Cohen (eds), Migration, diasporas and transnationalism Elgar, Cheltenham, 396-419.

Sheller, M and Urry, J. (2006), 'The new mobilities paradigm', Environment and Planning A 38, 207 - 226. 
Schwanen, T and Kwan, M. (2012), Critical space-time geographies

Environment and Planning A 44, 2043 - 2048

Soysal, Y. (1998), Towards a postnational model of membership, in: G. Shafir (Ed.), The Citizenship Debates: A Reader,189-221. Minneapolis, MN:

University of Minnesota Press, 189-221.

Thrift, N. (1996), Spatial formations Sage, London.

Thrift, N. and Pred, A. (1981), Time-geography: a new beginning, Progress in Human Geography, 5, 277-286.

Thrift, $\mathrm{N}$ and Dewsbury, J.D. (2000), 'Dead geographies and how to make them live', Environment and Planning D: Society and Space 18, 411-432.

Tolia-Kelly, D. (2006), 'Affect - an ethnocentric encounter? Exploring the 'universalistic' imperative of emotional/affective geographies', Area 28, 213217.

Werbner, P. (2004), 'Theorising complex diasporas: purity and hybridity in the South Asian public sphere in Britain', Journal of Ethnic and Migration Studies 30 (5), 895-911.

Werbner, P. (2002), 'The place which is diaspora: citizenship, religion and gender in the making of chaordic transnationalism', Journal of Ethnic and Migration Studies 28 (1), 119-133.

Wimmer, A. and Glick-Schiller, N. (2002), Methodological nationalism and beyond: nation-state building, migration and the social sciences, Global Networks, 2(4), 301-334.

Yeh, E.T. (2007), 'Exile meets homeland: politics, performance, and authenticity in the Tibetan diaspora', Environment and Planning D: Society and Space 25, 648-667. 
Yeoh, B. and Huang, S. (2000), 'Home and away: foreign domestic workers and negotiations of diasporic identity in Singapore Women's Studies', International Forum 23 (4), 413-429. 